\title{
A late Holocene pollen record from Lake Almalou in NW Iran: evidence for changing land-use in relation to some historical events during the last 3700 years
}

\author{
Morteza Djamali ${ }^{\mathrm{a}, *}$, Jacques-Louis de Beaulieu ${ }^{\mathrm{a}}$, Valérie Andrieu-Ponel ${ }^{\mathrm{a}}$, Manuel Berberian ${ }^{\mathrm{b}}$, \\ Naomi F. Miller ${ }^{c}$, Emmanuel Gandouin ${ }^{a}$, Hamid Lahijani ${ }^{d}$, Majid Shah-Hosseini ${ }^{\mathrm{d}}$, Philippe Ponel ${ }^{\mathrm{a}}$, \\ Mojtaba Salimian ${ }^{\mathrm{e}}$, Frédéric Guiter ${ }^{\mathrm{a}}$

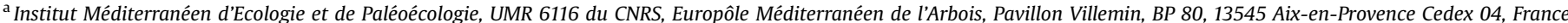 \\ b 1224 Fox Hollow Drive Toms River, NJ 08755-2179, USA \\ ${ }^{\mathrm{c}}$ Museum Applied Science Center for Archaeology (MASCA), University of Pennsylvania Museum, Philadelphia, PA 19104, USA \\ ${ }^{\mathrm{d}}$ Iranian National Center for Oceanography (INCO), No.9 Etemad Zadeh St., West Fatemi Ave, 14155-4781 Tehran, Iran \\ e Department of Plant Science, School of Biology, College of Science, University of Tehran, 14155-6455 Tehran, Iran
}

A pollen diagram was prepared from Lake Almalou, a volcanic crater wetland located on the eastern flanks of the Sahand Volcanic Complex in NW Iran. The core provides a 3700-year record of human activity and environmental change in an upland region. We attempt to relate vegetation changes to both climatic change and historical events. Variations of anthropogenic pollen indicators suggest several phases of intensified human activities. Two strongly expressed agricultural phases are dated at about $2450-2220$ cal BP (Achaemenid Empire) and 230-30 cal BP (collapse of Safavid Dynasty to the modern period). Historical rather than climatic events appear to be the main controlling factors for upland land-use dynamics. Fruticulture has been practiced in the region at least since the Iron Age, reaching its maximum importance 1500-1250 cal BP during the reign of Sassanid Empire; it declined by the time of Islamic conquest of Iran (651 AD). The Little Ice Age is tangibly recorded by higher lake water levels most probably due to both lower summer temperatures and higher annual precipitations. Low values of cereal-type and cultivated tree pollen during this period may indicate a change in the lifestyle from the cultivation of fields and orchards to a more nomadic life dominated by summer pasture. The modern period ( $1850 \mathrm{AD}$ onwards) is characterized by expansion of agricultural activities to upland areas and intensified pastoralism.

\section{Introduction}

Palynological studies provide a useful tool for the reconstruction of the Quaternary vegetation dynamics in response to climatic variations and human activities. During the last decades, ample Late-glacial-Holocene pollen records have been amassed for the Near East (e.g., Roberts and Wright, 1993; Van Zeist and Bottema, 1991). In western and northwestern Iran and eastern Anatolia, global climatic change led to the gradual replacement of Artemisia steppe by pistachio-oak scrub during the Late-glacial and Early Holocene, followed by the expansion of open oak forests at about 6500 cal BP (Bottema, 1986; Van Zeist, 1967; Van Zeist and Bottema, 1977; Wick et al., 2003). In several palynological studies, efforts have also been made to correlate mid- to late Holocene environmental changes with human occupation phases and historical periods and events (Bottema and Woldring, 1984, 1990; Heim et al., 1997; Yasuda et al., 2000; Neumann et al., 2007). These studies highlight the profound human impact on the development and establishment of modern vegetation and landscape in the Near East. However, almost all of the available Near Eastern pollen diagrams are from lakes located at elevations lower than 1500 m a.s.l. (e.g. data in Roberts and Wright, 1993). These can provide direct evidence for agro-pastoral activities only from midaltitudes and lowland regions, areas which have always been submitted to relatively dense human occupation and more intensive land-use than the upland regions of the Iranian Plateau. The Almalou core provides a late Holocene record of mountain vegetation of eastern foothills of the Sahand Mountain.

The Almalou bog is a high altitude site (2500 ma.s.l.) situated above the Zagros oak tree line in a fertile land heavily cultivated with cereals in northwestern Iran which has undergone a very long history of human-environment interactions (Zohary, 1983). Historically, the area has been a border zone between the civilizations of the Iranian Plateau, Asia Minor, the Caucasus, and 
Mesopotamia. The Almalou late Holocene pollen record may thus provide an exceptional opportunity to study the human activities in an upland area in the Near East. The aims of this paper can be summarized as:

1. Reconstructing the local and regional vegetation change of the Lake Almalou region (Sahand Mountain) during the late Holocene (past 3700 years),

2. Detecting the phases of intensified human activities in the form of agro-pastoral activities and fruticulture,

3. Comparing the vegetation and environmental changes (including climate change) with socio-economic phases and historical events.

\section{Physical setting}

\subsection{Geology and landscape}

The study area (Fig. 1) is located in the Sahand Volcanic Mountain located in northwestern Iran, east of Lake Urumiyeh (Urmia), with peaks at elevation of $3707 \mathrm{~m}$ a.s.l. In summer, snow remains on the northern side of the mountains year-round, but disappears on the southern slope by early August. Preliminary random $\mathrm{K}-\mathrm{Ar}$ dates, with unknown errors and unidentified sampling locations, range from 13 to $0.8 \mathrm{Ma}$ (Innocenti et al., 1982). These authors in their Fig. 2 schematically show (i) 1.2-0.8 Ma calcalkaline volcanic rocks in central Sahand, encircled by (ii) $7.8 \mathrm{Ma}$ volcanics in the north and northeast, and (iii) 13-5.5 Ma rocks in the south. However, geomorphologically, the complete shape of the numerous volcanic cones and craters indicates that the volcano might also have had eruptions during the Holocene (Bordet et al., 1976; Berberian and Arshadi, 1977; Berberian and King, 1981). Lake Almalou $\left(37^{\circ} 39^{\prime} 55^{\prime \prime} \mathrm{N}, 46^{\circ} 37^{\prime} 55^{\prime \prime} \mathrm{E}, 2491 \mathrm{~m}\right.$ a.s.l) is a crater wetland complex formed on the top of one of these volcanic cones of PlioPleistocene age on the eastern flanks of the Sahand Mountain (Fig. 1). The lake is fed exclusively by direct precipitation, mainly as winter snowfall and spring rainfall. The lake level is high during the winter months and starts declining from the middle of spring, reaching its lowest level in September-October. When the lake level is lowest, only a small and very deep central pond remains, bordered by the exposed peat deposit. The presence of a small nearperennial spring in the village of Almalou situated at the SE foothills of the volcano suggests there may be a slow discharge of the lake water via a fracture system in the crater bedrock.

\subsection{Climate}

Data from the nearest meteorological station in Marāgheh (1477 m a.s.l.) (Fig. 1) shows that the climate of the study area is Mediterranean xeric-continental (Rivas-Martinez et al., 1997). Mean annual precipitation is $327 \mathrm{~mm}$ with two peaks occurring in April and November. Mean annual temperature is $12.5^{\circ} \mathrm{C}$ and the mean minimum and maximum temperatures of the coldest and warmest months of the year are $-3.7^{\circ} \mathrm{C}$ (January) and $26.1^{\circ} \mathrm{C}$ (July) respectively. The dry season lasts for 5 months from May to October. As Lake Almalou is located $1000 \mathrm{~m}$ higher than the Marāgheh station (Fig. 1), it is expected that annual precipitation must be considerably higher and annual and seasonal temperatures must be lower than the values given above.

\subsection{Vegetation}

In the Almalou peat, Cyperaceae (Carex spp.), Poaceae and mosses dominate the less water-logged areas and together constitute the most important peat-forming plants. Potentilla sp. grows in the open-water around the central pond and Potamogeton $\mathrm{sp}$. forms the floating vegetation. Polygonum cf. aviculare colonizes the eulittoral zone of the lake and is rather restricted to the most disturbed parts which have undergone intensive grazing. At present, the intra-crater slopes and the outer flanks of the volcano are under dry-farmed cereal cultivation by farmers settled at small villages at the foot of the volcano and surrounding areas. Overgrazed uncultivated pasture and arable land is characterized by the dominance of Chondrilla sp., Euphorbia sp., Malva sp., Taraxacum sp., Xeranthemum sp., and Verbascum sp., some of which are antipastoral herbs (Zohary, 1983). Astragalus spp., Centaurea spp., Cousinia spp., Eryngium sp., Gypsophila sp., Scabiosa sp., Trifolium sp., Hypericum sp., Artemisia and Poaceae are among the other most important constituents of the treeless vegetation around the lake. It is worth mentioning that in the Turkish language, Lake Almalou signifies the "Lake of Apple" which may indicate that extensive fruit tree cultivation, including apple orchards, occurred in the area in the past. Nowadays, the closest fruit trees grow at an elevation of $2150 \mathrm{~m}$ near the lake.

\subsection{Archaeological and historical context}

The Almalou region is relatively isolated and unpopulated, and has been rarely studied by archaeologists. The broader surrounding region, Azarbaijan (Azerbaijan) province of northwestern Iran, has a long history of human occupation, and provides an historical context for the discussion of the pollen core to follow. The oldest traces of human settlement in the region date to the Paleolithic, and include two cave sites north and west of Lake Urumiyeh (Coon, 1951) and three caves and seven open-air sites discovered on the Sahand Mountain south of Tabriz, east of the Lake (Sadek-Kooros, 1976). The closest Neolithic sites lie in the plains west and south of Lake Urumiyeh. Yanik Tapeh, located in the northwestern foothills of Sahand Mountain, about $100 \mathrm{~km}$ NW of Lake Almalou (53 km SW of the city of Tabriz on the eastern shore of Lake Urumiyeh), dates as early as $6000 \mathrm{BC}$, continuing to the 1st millennium BC (Burney, 1961, 1962, 1964; Burney and Lang, 1972; Edwards, 1986; Ehrich, 1992). Hajji Firuz lies south of Lake Urumiyeh, about $130 \mathrm{~km} \mathrm{SW}$ of Lake Almalou. Plant remains from the site show that wheat and barley were cultivated as early as the 6th millennium BC (Voigt, 1983). Residues on ceramic jars from the site also yielded the earliest evidence for grape wine (McGovern et al., 1996), though it is not clear whether the grapes used were from wild or cultivated plants (Miller, in press).

Archaeological evidence relates sociocultural developments in Azarbaijan to the larger West Asian world in subsequent millennia. Material culture of the Chalcolithic (5th millennium BC) site of Pisdeli can be related to the "Ubaid of Mesopotamia" (Dyson and Young, 1960). The region near Lake Almalou lies with the archaeologically defined Bronze Age Kura Araxes and Trialeti cultures of the third and second millennia BC; culturally, the region is at the crossroads of Mesopotamia, Anatolia, the Caucasus, and the Zagros. By the latter half of the 2nd millennium BC, cereal and pulse cultivation, irrigation agriculture, and fruit-growing were all known in northwestern Iran (Miller, 2003). Cycles of land-use emphasizing farming and herding, sedentarism and nomadism that characterize the later periods, had already begun.

The Iron Age saw a succession of competing kingdoms in the region: Urartu, Assyria, Mannea, and Media. From 840 BC to the end of the 7th century BC, the Kingdom of Mannea/Mannai ruled the area southeast of Lake Urumiyeh, surrounded by three major powers: Assyria to the southwest, Urartu [Ararat] to the west and northwest, and Media [Māda, Medes] to the south. On a number of occasions the Assyrians and their northern rivals the Urartians invaded the lands in the west and the south of Lake Urumiyeh. The 

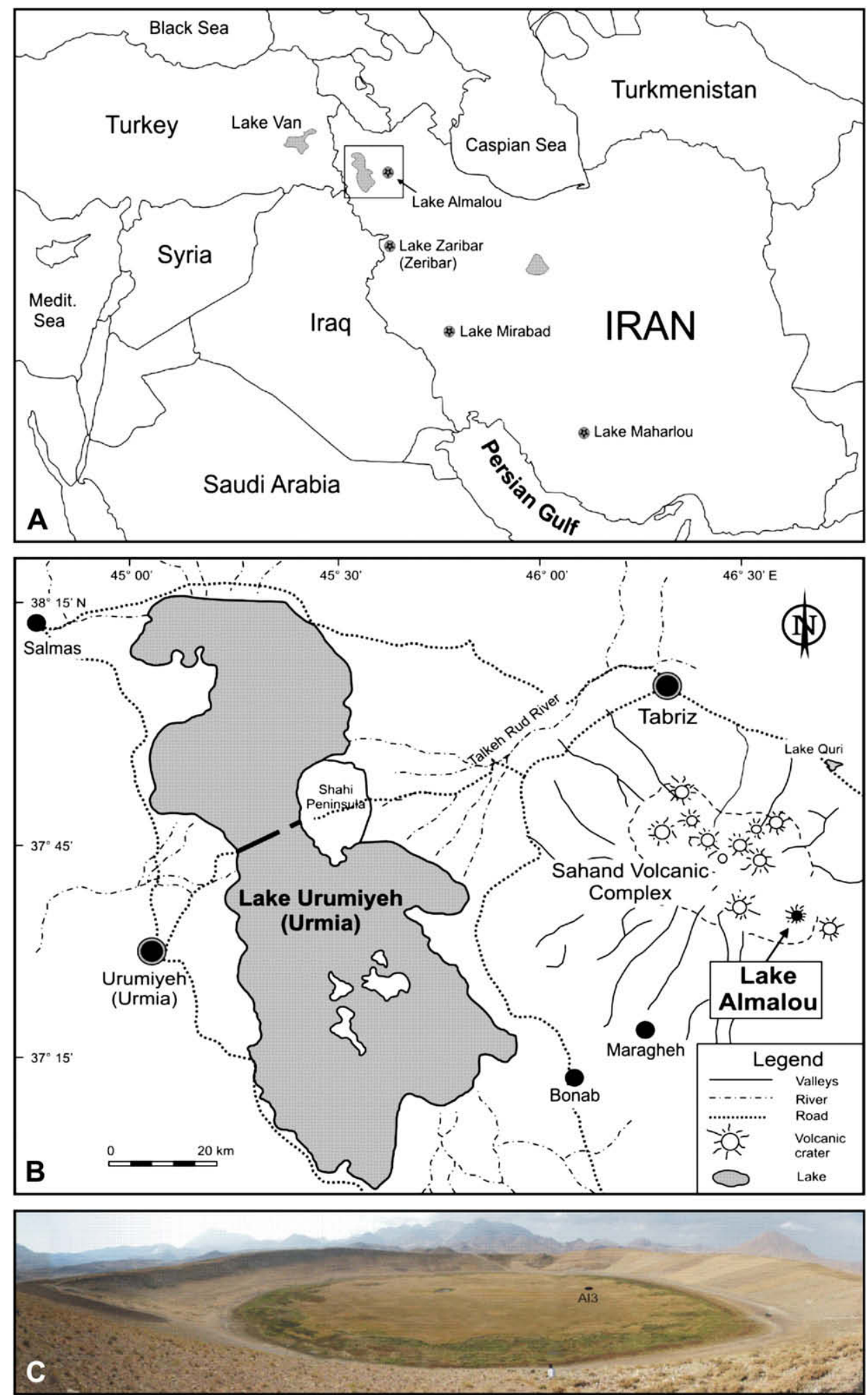

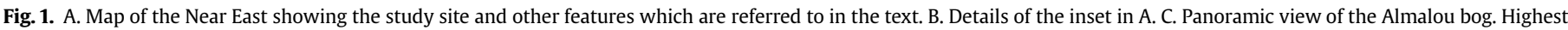
peaks of Sahand Mountain $(\sim 3700 \mathrm{~m})$ are observed in the background. Al3 indicates the location of the studied core.

main occupation of Hasanlu, located to the SW of Sahand near the southern shore of Lake Urumiyeh, dates to this period. First occupied in the Bronze Age, it had become a major fortified site, yet is thought to have been a center "for a largely transhumant tribal population living in the surrounding valley and uplands" (Danti,
2006-2008). It was attacked and burned around 800 BC. The habitation on the site ceased for a long time afterwards, and the surrounding country was sacked and ravaged. From $800 \mathrm{BC}$ to the mid-seventh century $\mathrm{BC}$, the Urartians held the districts southwest, west, northwest, and northeast of Lake Urumiyeh, 


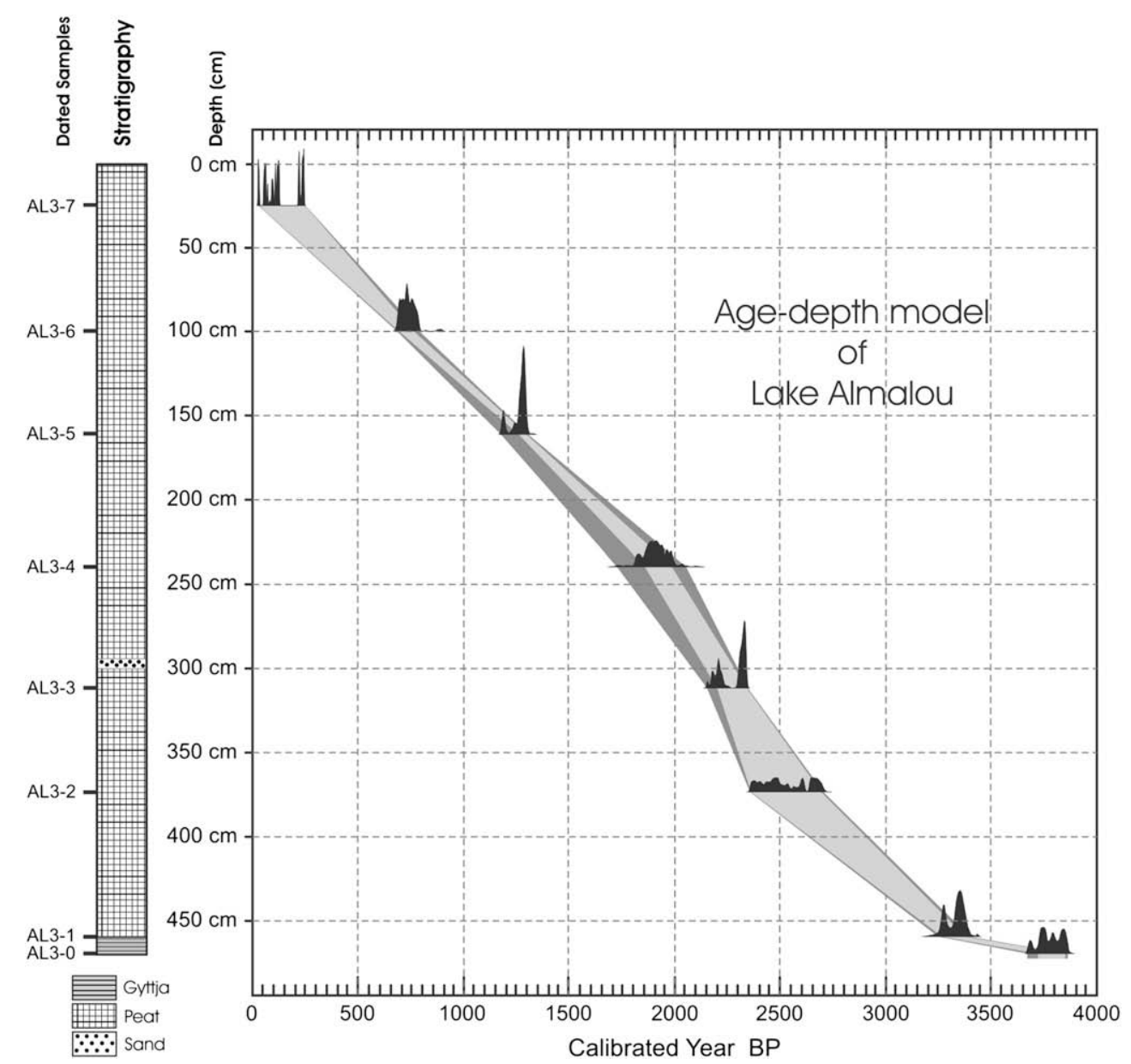

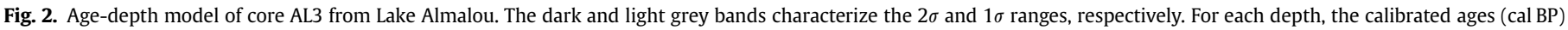
corresponding to the highest peaks of probability curves display the most probable ages.

where more than hundred Urartian forts, sites, and inscriptions have been identified (Kleiss, 1973a,b, 1974, 1977; Kleiss and Kroll, 1979). At the Urartian fortress of Bastam, about $250 \mathrm{~km} \mathrm{NW}$ of $\mathrm{L}$. Almalou, grape, almond, apricot, and lime (Tilia) fruits were found, along with cereals, pulses, millets, and sesame (Hopf and Willerding, 1988). With the rise of the Medes in the 7th century BC, the Mannaeans lost their identity and were subsumed under the term Medes (König, 1934; Medvdskaya, 1988; Melikishvili, 1949; Minorsky, 1957).

Some time in the second half of the 6th century BC, Azarbaijan was annexed to the vast Achaemenid Empire. The few Achaemenid remains in this province include graves and houses at Takht-e Solaymān and other burial sites (Huff, 1969-74, 1977, 1978; Naumann and Naumann, 1976) and at Qaleh Zahāk, above the railroad tunnel between Miyāneh and Marāgheh, $15 \mathrm{~km}$ south of Sareskand (Kleiss, 1973b). Achaemenid administration in much of the empire oversaw agricultural development (see, for example, Sumner, 1986).

During 331 BC-330 BC, the Achaemenid Empire collapsed with the invasion of Alexander III of Macedonia. Iranian resources, lives, property, institutions, and infrastructure were devastated. No progress was made under Alexander's successors, the Seleucids (312 BC-250 BC) (Yarshater, 1983a,b). Later, Azarbaijan became a separate administrative region under the Parthians (250 BC224 AD). Over the next few centuries, the Sassanian Empire ruled much of Iran. Despite some ups and downs in the economy (Yarshater, 1983a,b; Gyselen, 1989a,b), overall the Sassanianians invested in irrigation infrastructure which enabled highly productive agriculture (cereals, pulses, forage, fruits and vegetables) (Adams, 1981; Wenke, 1975-6; Rahimi-Laridjani, 1988).

Azarbaijan, with the rest of Iran, fell to the Arab Muslims during the mid-seventh century AD invasion. Once again, the economic prosperity, resources and infrastructure were devastated and agricultural activities and living conditions dramatically deteriorated. The oppressive rule of the Arab Caliphates during the first few centuries of Arab control gave rise to a number of Iranian rebellions. Azarbaijan's history in the first four centuries of the Islamic period is to a large extent obscure. There are no archeological remains in the plain north of the Sahand Mountain, and the earliest date of establishment of the city of Tabriz given in a literary source is $791 \mathrm{AD}$ (Mostaufi, 1340).

For most of the 11th-19th centuries AD, a succession of Central Asian Turk tribes ruled Azarbaijan. In $1222 \mathrm{AD}$ and $1231 \mathrm{AD}$, the Mongols sacked Marāgheh in Azarbaijan. Tabriz became the capital of the Il-khans in the 13th century and of the Qara Qoyunlū and Āq Qoyunlū Turkmen dynasties in the 15th century. Between $1381 \mathrm{AD}$ and 1405 AD Turk Tamerlane destroyed more cities and lands and slaughtered additional people (Boyle, 1968). Recurring destruction, massacre, confiscation, and plundering the wealth, arable lands, and irrigation networks impeded economic development for centuries. The relatively long period of stability under the Safavids (1491 AD-1736 AD) resulted in prosperity, construction and the development of much of Iran (Bosworth, 1989), but Azarbaijan was on several occasions invaded and occupied by Ottoman Turks (Birken, 1976; Jackson and Lockhart, 1986; Bosworth, 1989). 


\section{Materials and methods}

A 470-cm core (AL3) was taken from the marginal parts of the Almalou peat bog using a Russian-type borer in September 2006 when the lake water was lowest. The basal part of the core is composed of gyttja $(470-460 \mathrm{~cm})$ which changes into a fibrous peat up to the surface except for a $2 \mathrm{~cm}$-thick sand layer found at about $295 \mathrm{~cm}$ (Fig. 2). Chronology is based on 8 AMS radiocarbon ages performed at Poznań Radiocarbon Laboratory (Table 1). All ${ }^{14} \mathrm{C}$ ages were calibrated by Calib 5.0.2 (Stuiver et al., 1998) and are reported in Table 1. The age-depth model was created by plotting the distribution probability density curves for each dated level on agedepth diagram (Fig. 2). For any given depth, the ages corresponding to the highest peaks are the most probable real ages. A calibrated chronological scale (cal BP) was then constructed for the Almalou record based on the above age-depth model by interpolating calculated mean age values with $2 \sigma$ error ranges (Figs. 3-5).

Pollen extraction followed Moore et al. (1991). Lycopodium tablets were added to the samples to calculate the pollen concentrations (Stockmarr, 1971). Pollen determinations were performed by using the IMEP pollen reference slides collection and pollen atlases of Reille (1992, 1995, 1998), Beug (2004) and pollen morphological descriptions by Van Zeist and Bottema (1977). Calculation of pollen percentages and concentrations was performed with TILIA and the pollen diagrams (Figs. 3 and 4) were created in TGView software (Grimm, 2004/2005). Pollen percentages of the aquatic plants including Cyperaceae were excluded from the total pollen sum. The Cereal-type pollen was also excluded because of the very high values in some levels which could mask the importance of other terrestrial plants.

A preliminary chironomid (Insect, Diptera) subfossil analysis was performed at the bottom of the sequence in order to investigate the main hydrological change which occurred at the gyttja/ peat transition. Thus, two $1 \mathrm{~cm}$-thick sediment samples were preleved at $464-465$ and $374-375 \mathrm{~cm}$. The laboratory methods for the extraction of subfossil remains consist of a coupled method, with successive sediment $\mathrm{KOH}\left(10 \%\right.$; $\left.70^{\circ} \mathrm{C}\right)$-defloculation, waterwashing over a $100 \mu \mathrm{m}$ sieve (Hofmann, 1986) and paraffin flotation (Coope, 1986).

\section{Results and interpretation}

Simplified percentage and concentration pollen diagrams of Lake Almalou core AL3 are shown in Figs. 3 and 4. Pollen zonation is based on stratigraphically constrained cluster analysis performed in Coniss (Grimm, 1987, 2004/2005) with some minor modifications. In a pollen diagram from a given site, a Local Pollen Assemblage Zone (LPAZ) is defined as a body of sediment with a consistent and homogeneous fossil pollen content different from the adjacent zones (Birks and Birks, 1980). Seven Local Pollen Assemblage Zones (LPAZs) have been distinguished (Figs. 3 and 4). In general, the pollen of upland plants like Artemisia and Quercus do not show significant variations all along the core which indicates no major change in regional vegetation during the last 3700 years. The detailed description of the pollen zones is described and interpreted as follows.

LPAZ A. This pollen zone is dated between 3750 and 3400 cal BP (Figs. 2 and 3). Pollen percentage values of the submerged hydrophytes like Myriophyllum and Polygonum amphibium and Sparganium/Typha are very high and Polygonum aviculare-type and Cyperaceae show relatively higher frequencies than in the next pollen zone. Dominance of submerged aquatic plants combined with the deposition of gyttja (Fig. 2) suggests that the Almalou bog system was then a shallow permanent lake with a narrow eulittoral zone colonized by Typha spp. and/or Sparganium, Polygonum sp., Cyperaceae and probably Poaceae. Peat formation may have been limited to marginal lake environments.

Only twenty chironomid head capsules have been extracted from the whole sample at $464 \mathrm{~cm}$ (Table 2). This is lower than the minimum of 50 head capsules per samples required to make realistic estimates of environmental conditions (Quinlan and Smol, 2001). However, the abundance of Chironomus anthracinus-type (20\%), which is often predominant in profundal zone of deep lakes (Vallenduuk and Moller Pillot, 2002) is in agreement with the hypothesis of a dominant open lake environment. C. anthracinustype is also a warm-water adapted and eutrophic taxon able to survive under low-oxygen water conditions. The presence of Lauterborniella agrayloides confirms the eutrophic status of the water (Moller Pillot and Buskens, 1990).

LPAZ B. This pollen zone which corresponds to the period between 3400 and 2500 cal BP is characterized by Potentilla micrantha pollen type and the intermittent presence of Botryococcus and Pediastrum. Towards the end of this pollen zone, Artemisia pollen reaches relatively high values. Presence of a peak of Non-Pollen Palynomorph (NPP) types 200 and 201 (Van Geel et al., 1989) which are associated with decomposition of plant remains on temporarily desiccating ponds may indicate a longer seasonal exposure of the peat and/or pond at around 3350 cal BP.

A total of 51 chironomid head capsules have been extracted from the peaty sample at $374 \mathrm{~cm}$. In spite of the dominance of the Tanytarsini tribe of a large ecological range, the disappearance of C. anthracinus-type in favour of more littoral and macrophyteinhabiting taxa, such as Dicrotendipes (Hofmann, 1984) or Corynoneura scutellata-group (Moller Pillot and Buskens, 1990) may indicate a reduction of the open-water area to the benefit of peat extension. The abundance of Psectrocladius sordidellus-type suggests probable acidification of the water by increasing humic acid inputs (Ilyashuk et al., 2005). This is also consistent with peatgrowth and the natural acidification of the lake. The presence of Limnophyes, a semi-terrestrial taxon (Wiederholm, 1983), indicates the emergence of a lakeside marsh that likely developed along the lake's edges as water levels receded (Potito et al., 2006).

High values of $P$. micrantha-type pollen indicates the expansion of the floating peat layer from the lake margins into the centre of the crater. The disappearance or decreasing values of submerged

Table 1

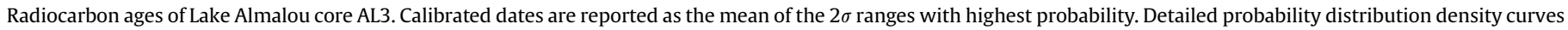
of calibrated ages are illustrated in Fig. 2.

\begin{tabular}{|c|c|c|c|c|c|}
\hline Sample No. & Depth $(\mathrm{cm})$ & Lab code & ${ }^{14} \mathrm{C}$ age (yr BP) & Calibrated age (cal yr BP) & Material dated \\
\hline$\overline{A L 3-7}$ & $24-25$ & Poz-23327 & $105.84 \pm 0.33$ & $239 \pm 16$ & Peat \\
\hline AL3-6 & $99-100$ & Poz-23326 & $830 \pm 30$ & $737 \pm 51$ & Peat \\
\hline AL3-5 & $160-161$ & Poz-23324 & $1340 \pm 30$ & $1270 \pm 36$ & Peat \\
\hline AL3-4 & $239-240$ & Poz-23323 & $1960 \pm 50$ & $1927 \pm 115$ & Peat \\
\hline AL3-3 & $311-312$ & Poz-23322 & $2285 \pm 30$ & $2326 \pm 25$ & Peat \\
\hline AL3-2 & $373-374$ & Poz-23321 & $2450 \pm 30$ & $2452 \pm 93.5$ & Peat \\
\hline AL3-1 & $459-460$ & Poz-21117 & $3110 \pm 30$ & $3352 \pm 68$ & Gyttja \\
\hline AL3-0 & $469-470$ & Poz-23320 & $3465 \pm 30$ & $3756 \pm 75$ & Gyttja \\
\hline
\end{tabular}




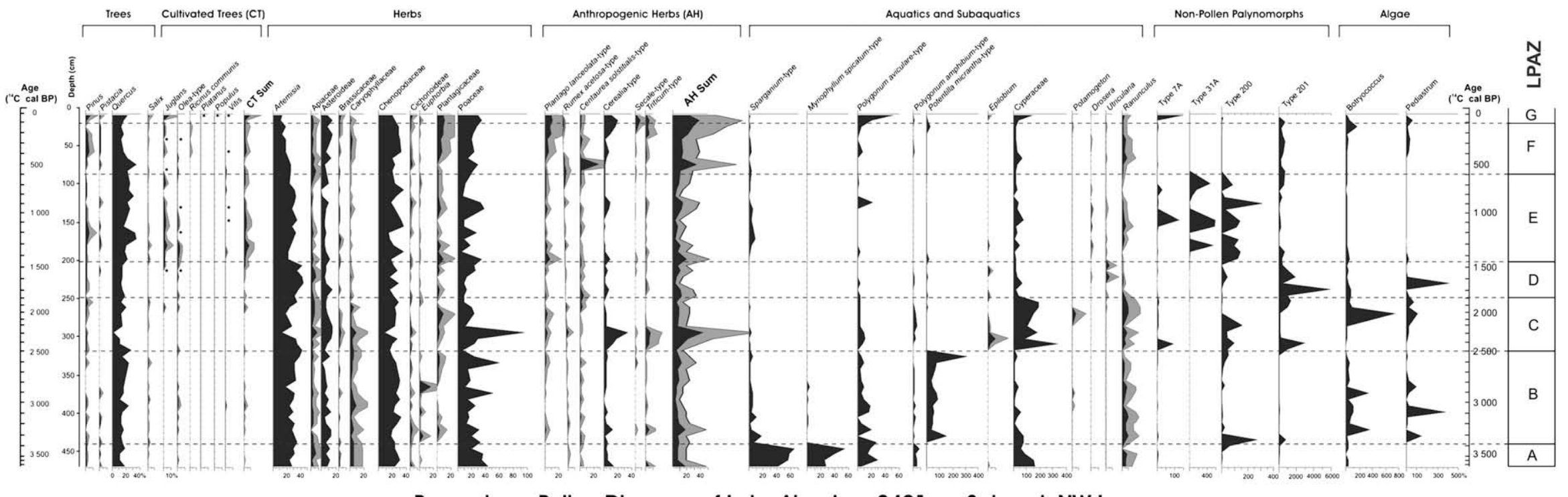

Percentage Pollen Diagram of Lake Almalou, 2491 m, Sahand, NW Iran

Fig. 3. Pollen percentage diagram of Lake Almalou core AL3. Curves filled with grey display $\times 3$ exaggeration. Filled circles show values less than $0.5 \%$.

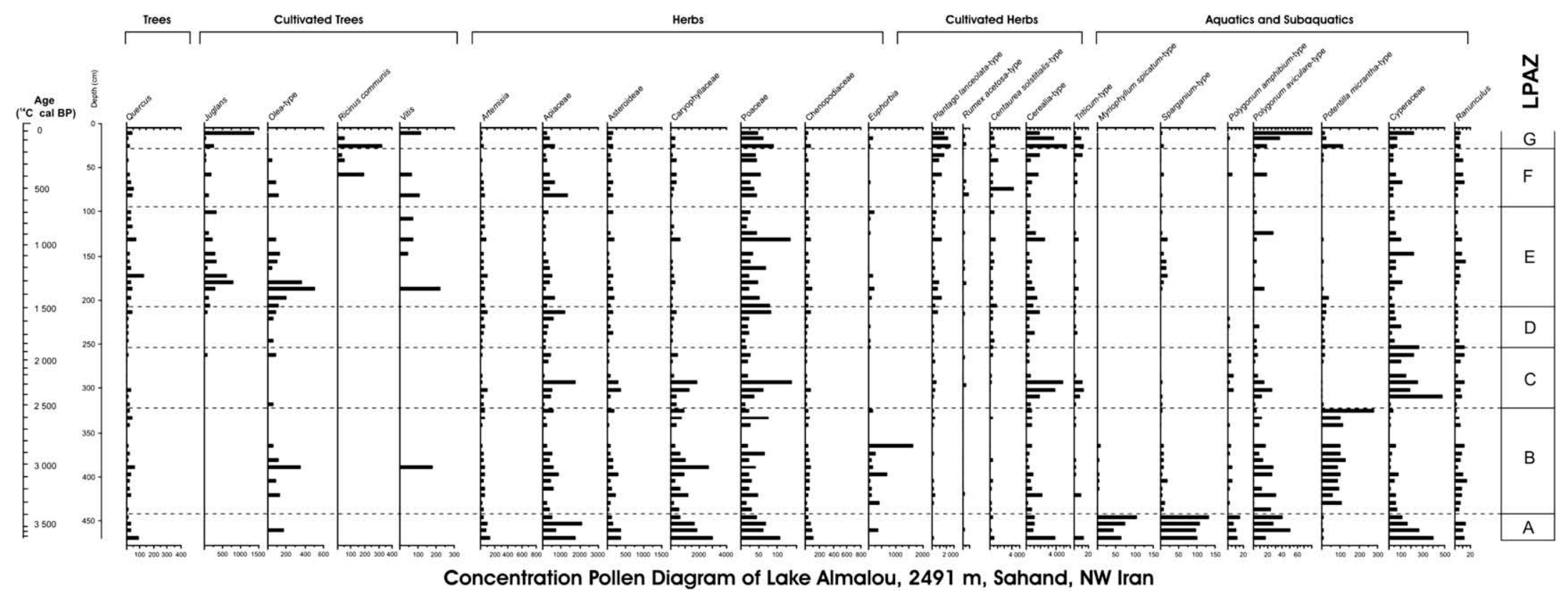

Fig. 4. Pollen concentration diagram of a selection of taxa. Concentrations are in number of pollen grains per $\mathrm{cm}^{3}$. 


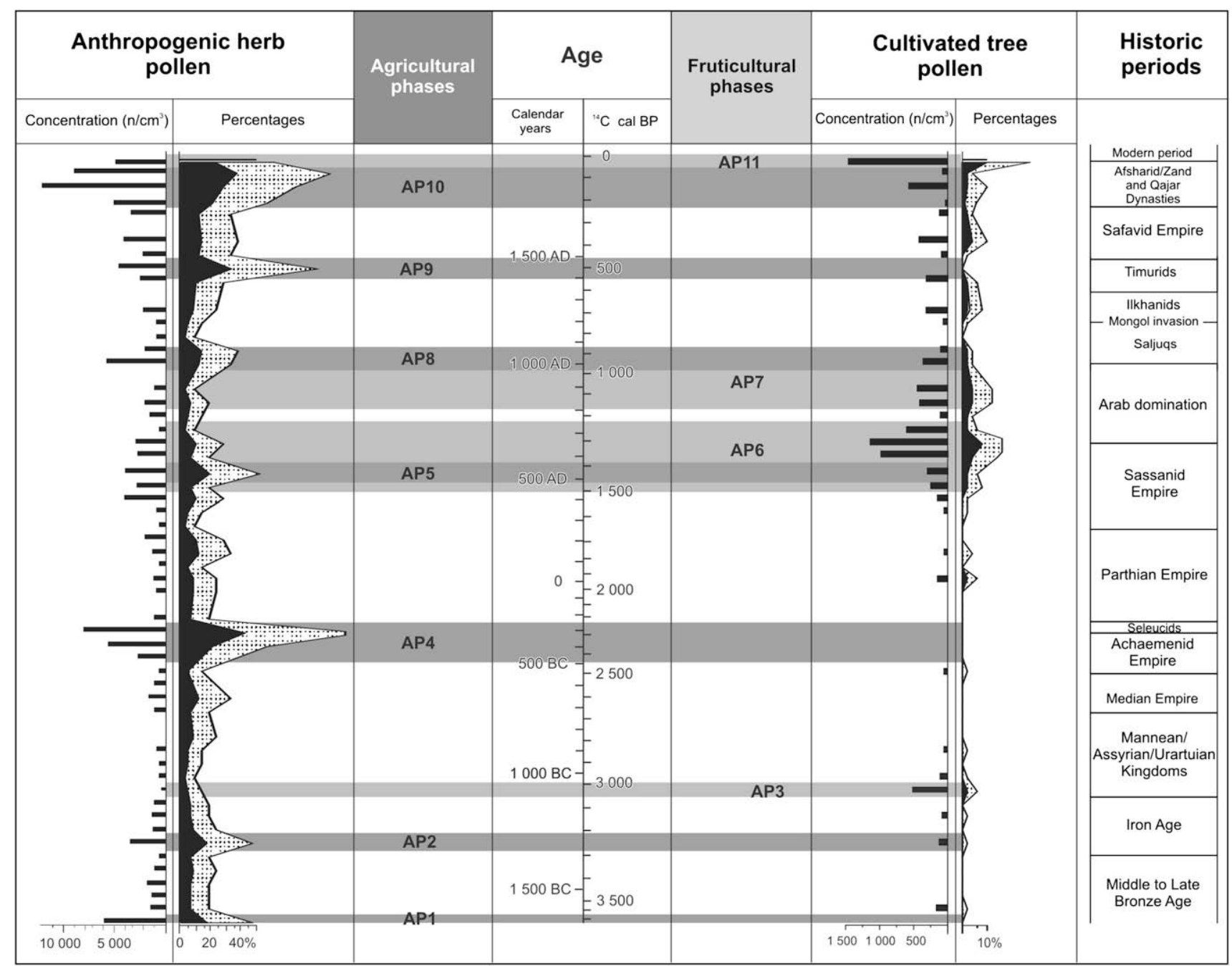

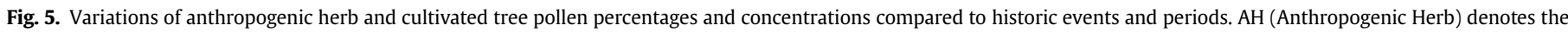
sum of the pollen grains of anthropogenic herbs and CT (Cultivated Trees) shows those trees planted by man including Juglans, Olea, Vitis, Platanus, and Populus.

Table 2

Subfossil chironomid assemblages from the basal part of the Almalou lake sequence, at the gyttja/peat transition.

\begin{tabular}{|c|c|c|c|c|c|}
\hline Depth $(\mathrm{cm})$ & Sediment & Volume $\left(\mathrm{cm}^{3}\right)$ & Taxa & \multicolumn{2}{|c|}{$\begin{array}{l}\text { Abundance (number of } \\
\text { head capsules/relative) }\end{array}$} \\
\hline $374-375$ & Peat & 28 & $\begin{array}{l}\text { - Other Tanytarsini tribe } \\
\text { - Psectrocladius sordidellus group } \\
\text { - Paratanytarsus/Tanytarsus } \\
\text { - Micropsectra } \\
\text { - Other Chironomini tribe } \\
\text { - Dicrotendipes } \\
\text { - Glyptotendipes } \\
\text { - Polypedilum } \\
\text { - Chironomus plumosus-type } \\
\text { - Corynoneura scutellata group } \\
\text { - Limnophyes } \\
\text { - Other Diptera (type A) }\end{array}$ & $\begin{array}{r}12 \\
11 \\
9 \\
2 \\
3 \\
2 \\
1 \\
1 \\
1 \\
5 \\
2 \\
2\end{array}$ & $\begin{array}{l}23.5 \% \\
21.6 \\
17.6 \\
3.9 \\
5.9 \\
3.9 \\
2.0 \\
2.0 \\
2.0 \\
9.8 \\
3.9 \\
3.9\end{array}$ \\
\hline $464-465$ & Gyttja & 28 & $\begin{array}{l}\text { - Other Tanytarsini tribe } \\
\text { - Psectrocladius sordidellus group } \\
\text {-Paratanytarsus } \\
\text { - Lauterborniella agrayloides } \\
\text { - Chironomus anthracinus-type } \\
\text { - Microtendipes } \\
\text { - Eukiefferiella }\end{array}$ & $\begin{array}{r}11 \\
1 \\
1 \\
1 \\
4 \\
1 \\
1\end{array}$ & $\begin{array}{l}55 \% \\
5 \\
5 \\
5 \\
20 \\
5 \\
5\end{array}$ \\
\hline
\end{tabular}


hydrophytes also shows that these plants received less sunlight due to less open-water conditions and centripetal migration of the floating peat towards the central part of the crater. However, the sporadic presence of low pollen percentages of these plants combined with Botryococcus and Pediastrum indicates that the lake may have experienced a few high stand phases centred at ca 3300 , 3100 and 2900 cal BP. At around 3000 cal BP the Olea pollen values coincide with a small peak of Vitis. Caution should be taken when interpreting such low values in terms of fruticultural activities as, e.g., Olea pollen can easily be transported over long distances and may represent background percentages (Woldring and Bottema, 2001/2002). However, Vitis is an extremely under-represented taxon in pollen rain and even its lowest values could show the presence of a close vineyard (Turner and Brown, 2002). This phase is thus interpreted as a possible development in viticulture at a regional scale.

LPAZ C. Centripetal development of the floating peat continues during the deposition of this pollen zone dated between ca. 2500 and ca. 1800 cal BP. Very high values of Cyperaceae pollen which currently constitutes the most important peat-forming plant of the Almalou bog system, shows that the site is completely covered by the sedge peat by $2400 \mathrm{cal} \mathrm{BP}$. A small peak of NPP type 7A (Chaetomium sp.) is in accordance with the establishment of this sedge bog (Van Geel et al., 1989). The concomitant peaks of Potamogeton, Pediastrum and Botryococcus at $270 \mathrm{~cm}$ (ca. $2000 \mathrm{cal} \mathrm{BP}$ ) show a temporary period of higher lake water level which may correspond to a short period of slightly increased precipitations and/or lower annual temperatures.

The lower part of LPAZ C is characterized by the maximum value of Cerealia-type pollen (35\%) throughout the Almalou record (Figs. 3 and 4). Triticum-type pollen which is produced almost certainly by the genus Triticum accounts for a significant part of this peak (Beug, 2004). As autogamous cereals such as Hordeum, Triticum and Avena are extremely under-represented in modern pollen rains (e.g. Behre, 1981), this peak undoubtedly indicates that cereal (wheat) cultivation was practiced within and outside the Almalou crater between 2450 and 2250 cal BP. The direct inwash of the cereal pollen from the cultivated intra-crater slopes has certainly increased the pollen concentrations into the peat which is confirmed by the deposition of a sand layer within the peat (Fig. 2).

LPAZ D. From this pollen zone upwards, the peat completely choked the crater site and an ecosystem homologous to the present one became established. LPAZ D (ca. 1800-1450 cal BP) starts with a sudden decline of Cyperaceae and a high representation of NPP type 201. These markers could indicate longer episodes of aerial exposure of peat deposit. Although Artemisia pollen percentages show relatively higher percentages (Fig. 3), low concentration values of this taxon (Fig. 4) do not clearly confirm the possibility of a drought climatic event. Towards the end of this pollen zone, the curve of fruit tree pollen becomes continuous indicating the development of the fruticulture at this time.

LPAZ E. The most characteristic feature of this pollen zone is the dominance of NPP types 7A, 31A and 200 (Van Geel et al., 1989; Van Geel and Aptroot, 2006). The explosion of the remains of fungi associated with the decomposition of cellulose type 7A (Van Geel, 1978) and type 200 (Van Geel et al., 1989) most probably shows the longer episodes of peat exposure. NPP type 31A has already been reported to be associated with Carex limosa, Meesia triquetra and Sphagnum by Van Geel et al. (1989). Its occurrence in the Almalou sequence is contemporaneous with the presence of remains of $M$. triquetra (H. Kürschner, personal communication). This event could show a host-specific relashionship with this moss.

The pollen of fruit trees forms a continuous curve in LPAZ E except for two falls at about $173-163 \mathrm{~cm}(1270-1200 \mathrm{cal} \mathrm{BP})$ and $120-112 \mathrm{~cm}(860-790 \mathrm{cal} \mathrm{BP})$ (Figs. 3 and 4). These two phases also correspond to the decreased values of cereals and other anthropogenic herbs (Fig. 3).

LPAZ F. In this pollen zone (ca. 600-100 cal BP), NPP types associated with the decomposition of plant remains disappear whereas Botryococcus and Pediastrum reappear. This most probably indicates shorter exposure times of the peat and therefore higher lake levels. Such peat/mire surface wetness changes have already been reported from NW Europe and have been linked to periods of mimimum solar activities (Mauquoy et al., 2002). The chronology of this pollen zone coincides with the Little Ice Age (LIA) which occurred at about 1250 AD-1880 AD with a more pronounced phase between $1550 \mathrm{AD}$ and $1850 \mathrm{AD}$ (Bradley et al., 2003). The LIA high water table could have been induced by lower evaporation due to the lower summer temperatures and/or higher annual precipitations. During the LIA, decreased evaporation and increased precipitation over the huge Caspian drainage basin in NW Eurasia induced by positive North Atlantic Oscillation (NAO) index phases have caused the latest highstand of the Caspian Sea (Kroonenberg et al., 2007). However, it has been demonstrated that winter precipitations and temperatures in the Mediterranean region are anti-correlated with the positive NAO (Luterbacher and Xoplaki, 2003; Nesje and Dahl, 2003; Touchan et al., 2005). Hence, the high annual precipitations would not have occurred in NW Iran as the climate of NW Iran is primarily controlled by wet air masses originated from the westerlies reinforced over the Mediterranean and Black seas (Stevens et al., 2001) which are anticorrelated with the positive NAO phases. However, on northern slopes of the Alborz Mountains, NW Iran, the occurrence of torrential rainfalls has been suggested as the cause of an important erosional episode during the second half of the 16th century AD (Ramezani et al., 2008). Reconstruction of May-September summer precipitation over the Anatolian Plateau and adjacent areas also shows that wet episodes were more frequent during the LIA compared to the previous Mediaeval period and the Modern period (Touchan et al., 2005). Summer temperatures may also have been lower than today during the LIA. A multi-proxy study proves lower LIA summer temperatures for western Europe (Guiot et al., 2005). In dendrochronological data from the southern Alps, summer temperature curves display lower minima than the average values during LIA (Serre-Bachet, 1994). The particular NPP composition and the appearance of Pediastrum and Botryococcus in LPAZ F may thus indicate that the Little Ice Age would have affected the NW Iranian plateau by lower annual (or summer) temperatures combined to episodic increases in the annual precipitations.

LPAZ F is also characterized by the reinforcement of human activities reflected in the Almalou pollen record by increased values of anthropogenic pollen indicators like Plantago lanceolata-type, Rumex, Cerealia-type and cultivated trees (Fig. 3). The first traces of Ricinus communis cultivation also appear in this zone dated at about $400 \mathrm{cal} \mathrm{BP}$.

LPAZ G. This pollen zone covers the last century. The most characteristic features are the highest amounts of anthropogenic herbs (e.g. cereals and $P$. lanceolata-type), cultivated trees and $P$. aviculare-type pollen. The latter plant most probably indicates the intensified stock grazing as this plant currently intensively colonizes the most disturbed areas in marginal lake-peat environments. The very high values of NPP type 7A and the sudden decline of Botryococcus and Pediastrum may show the very recent peat exposure due to drought events. Pollen of cultivated trees particularly Juglans reach the highest amounts.

\section{Discussion}

\subsection{Pollen indicators of agriculture and pastoralism}

Cerealia-type pollen has been used as the most important indicator of agricultural activities in the prehistoric time (e.g., 
Behre, 1981). In the Near East, this pollen type has a less indicator value for agriculture because it may also be produced by several wild grass species, some of which being considered as the likely ancestors of the modern cultivated cereals (Bottema, 1992, 1995; Behre, 1990; Van Zeist et al., 1975). However, not only is Lake Almalou outside the range of most of these species, but by the time of this pollen sequence, cereal cultivation in the near East was well established. Despite this difficulty, the Cerealia-type pollen can sometimes be assigned to certain genera with a high degree of certainty. In the Almalou record, the morphological features of many Cerealia-type pollen closely match the Triticum-type which includes at least Triticum aestivum, T. compactum, and T. spelta (Beug, 2004). Besides the Cerealia-type pollen as a direct evidence of agriculture, the sum of the Cerealia-type, P. lanceolata-type, Rumex acetosa-type, and Centaurea solstitialis-type pollen have been used in this study to make a synthetic curve to show the agropastoral activities (see e.g., Behre, 1990; Bottema and Woldring, 1984, 1990). P. lanceolata-type can indicate the extensive grazing and is frequently associated with disturbed areas in ruderal places and farmlands (Behre, 1981; Bottema and Woldring, 1984). C. solstitialis-type pollen is usually considered as a plant associated with cereal cultivation in the circum-Mediterranean and Near Eastern regions (Andrieu-Ponel et al., 2000; Bottema and Woldring, 1990). It has been reported in the recently ploughed cereal fields of several sites situated in the Anatolian Plateau and Greece (Bottema and Woldring, 1984). Its presence in the pollen diagrams of the Near East can therefore be taken as an indication of cereal cultivation. The $R$. acetosa-type pollen is produced by several species which are associated with weed and ruderal communities developed in wet meadows and pastures in Europe (Behre, 1981). Its anthropogenic indicator value appears less informative in the Near East but may be important in more humid areas (Bottema and Woldring, 1990).

\subsection{Pollen indicators of fruticulture}

In the present study, the tree pollen used to define fruticultural phases include Juglans, Olea, Vitis, and Ricinus. The curve representing the cultivated tree pollen (CT) in Figs. 3 and 5 was constructed by summing up the percentage values of these taxa. These taxa combined to Castanea, Fraxinus ornus, and deciduous Quercus, start increasing since during the so-called Beyşehir Occupation Phase (B.O. phase: ca. 3600-3400 cal BP) in the pollen diagrams from Asia Minor indicating an important socio-economic change (Bottema and Woldring, 1990). In the Almalou area, the very low winter temperatures prevent the cultivation of olive trees but are not too low for the growth of Juglans and Vitis. Hence the Olea pollen most probably shows an increase in olive cultivation in remote areas with milder winters like the southern Caspian region or the East Mediterranean region. The low pollen production of Juglans and notably Vitis (Bottema and Woldring, 1990; Turner and Brown, 2002) implies that even very low pollen values of these trees may indicate a cultivated origin. In the Almalou pollen diagram (Fig. 3) Juglans and Vitis attain values up to $7.9 \%$ and $0.92 \%$, respectively, which are sufficiently higher than the values presumed for tree cultivation (Bottema and Woldring, 1990; Turner and Brown, 2002). It should however be noted that the low relative frequencies of Vitis may not be a strong evidence of significant viticulture in the area. By 5000 cal BP grape occurs in the Zeribar sequence; by that time, cultivation had begun to spread down the Zagros, and therefore grape was probably cultivated near Urmiyeh, too (Miller, in press).

\subsection{Anthropogenic phases}

Variations in the percentage and concentration values of the anthropogenic pollen indicators in the Almalou record can be used to define several anthropogenic phases (Fig. 5). In total, eleven phases of intensified anthropogenic activities are distinguished, dated, and tentatively correlated to some historical periods and events in northwestern Iran during the last four millennia (Fig. 5). The most conspicuous feature of the synthetic diagram of Fig. 5 is the episodic occurrence of anthropogenic herb pollen maxima which, with the exception of the AP9 phase, are mainly composed of Cerealia-type pollen and fruit tree pollen (Fig. 3). Furthermore, almost all along the record, anthropogenic herb pollen form a continuous curve displaying low percentages compared to the anthropogenic phases. This is especially the case with pollen grains indicating cereal cultivation and pastoral activities. This background anthropogenic pollen may be an indication of a 'default' economy based on nomadism with the characteristic summer pasture. The nomadic pastoralism since long time has profoundly modified the natural vegetation of the Iranian highlands (Zohary, 1983; Klein, 1994). This type of lifestyle still continues in the high massifs of NW Iran including the Sahand and Sabalan Mountains. The most pronounced APs are two phases observed at intervals 2450-2220 cal BP (AP4, AH $=43 \%$ and Cerealia-type $=34 \%$ ) and 230-30 cal BP (AP10, $\mathrm{AH}=37 \%$ and Cerealia-type $=21 \%$ ). The older phase (AP4), with highest values of Cerealia-type pollen in the whole diagram, corresponds to the time of the Achaemenid Empire (Fig. 5) and indicates the upland expansion of cereal cultivation most probably associated with stronger grazing activities. The predominant form of economic activity in the majority of the lands, brought under the Achaemenid imperial rule with constructed irrigation system by the Achaemnids, was agriculture. Barley was the most frequently sown cereal in the empire while spelt and wheat were less frequently sown (Gershevitch, 1985; Dandamaev and Lukonin, 1989). One may also put forward the hypothesis according to which the local people invented an irrigation system using the animals and the water available in the Almalou crater lake. The most recent phase (AP9) begins after the collapse of the last great empire of Iran, the Safavid dynasty, and continues to less than a century ago. This period is particularly characterized by overgrazed pasturelands evidenced by the highest values of P. lanceolata-type pollen (Figs. 3 and 4). The finding of wheat cultivation at the beginning of the 4th millenium BC in the NW Iran does not come in surprise because the emmer wheat and freethreshing wheat cultivation can be traced up to the 6th-3th millennia BC in Tapeh (Tepe) Hajji Firuz to the SW of the Sahand Mountain (Zohary and Hopf, 1994). For AP9, no peak of Cerealiatype pollen is observed but the very important peak of $C$. solstitialistype pollen would be related to ploughing of the surrounding areas of the Almalou crater during the hot season (Bottema and Woldring, 1984, 1990). It may be that unlike other agricultural phases, the cereal-farming during AP9 was practiced outside the crater and the pollen could not be washed directly into the Almalou Lake.

The first tree cultivation phase (AP3, dated at about $3030 \mathrm{cal} \mathrm{BP}$ ) appears just after the beginning of the Iron Age and coincides with the native Iranian Mannean dynasty and the neighbouring Urartu and Assyrian empires in eastern Anatolia and Mesopotamia, respectively. This phase follows the so-called Beyşehir Occupation phase beginning at about ca. $3600-3400$ cal BP during which the pollen percentages of cultivated trees such as Olea, Juglans, Vitis, Platanus, and Castanea increase simultaneousely in almost all the pollen diagrams of Minor Asia and SE Greece (Bottema and Woldring, 1990). Absence of cultivated tree pollen and a drop in agricultural products during regional conflicts in Azarbaijan which led to the 714 BC eight campaign of Sargon II and destruction of Hasanlu, coincides with period between this fruiticultural phase and the appearance of the first Persian empires. In the Almalou region, the first large-scale tree cultivation phase is observed at 
about 1500-1250 cal BP (AP6) that coincides with the Sassanid Empire. As with the Achaemenid Empire, highly productive agriculture (cereals, pulses, forage, fruits and vegetables) with irrigation management infrastructure was the basis of the economy during the Sassanid Empire (Adams, 1981; Wenke, 1975-6; RahimiLaridjani, 1988). Cultivated tree pollen suddenly falls down just after the collapse of the Sassanids and the Islamic conquest which could have had a transitory destructive effect on the local agricultural system. However, fruticulture is re-established soon after this short-lived socio-economic crisis (AP7, 1170-900 cal BP). Since about $900 \mathrm{calBP}$ onwards, the cultivated tree pollen form an inconsistent curve. The Mongol invasion (1219 AD) and later Timurid period (1381 AD-1452 AD) followed by other unstable local governments coincide with this period of less developed agriculture and fruticulture occurring during this period between 900 cal BP and the Safavid era. Curiously, no pronounced fruticultural and agricultural event can be observed during the reign of the Safavid Dynasty, which is known to have created social, economic and political stability in Iran during the time span of 1491 AD$1736 \mathrm{AD}$. In this time, changes in NPP composition of the Almalou peat could indicate that the effect of climatic deterioration on vegetation has been as important as or maybe more important than the socio-economic changes. It is also possible that the increased precipitation and long-lasting snow cover in the high elevations due to the lower annual temperatures of the LIA may have favoured the nomadic lifestyle. The lack of developed agriculture and fruticulture can also be partly accounted for by the instability resulting from several conflicts and later episodic occupations by the Turkish Ottoman empire. An outstanding fruticultural feature in the Safavid period is the appearance of $R$. communis pollen at about $1550 \mathrm{AD}$. Bottema (1986) mentions the appearance of this pollen grain in a recent pollen diagram of Lake Urumiyeh (Urmia) but cannot provide a precise date for its cultivation. This plant (in Persian: Karchak) was domesticated in tropical Africa and spread to India about four thousand years ago (Harappan period) (Blench, 2003; De Candolle, 1964). In several pollen diagrams of south tropical Africa, this pollen grain is frequently encountered with low values but show a significant peak between 1500 and 1200 cal BP apparently due to deforestation and/or fruticultural activities (Guillaume Buchet, personal communication). The finding of Ricinus pollen during the Safavid period provides evidence for its introduction from Africa via the Ottoman Empire or less probably by direct marine transportation from east-central Africa or India via the Persian Gulf. No Ricinus pollen was found before 1500 AD confirming that it is not native to NW Iran, as suggested by Bottema (1986).

It is noteworthy that the peaks of fruticulture and agricultural (and/or pastoral) activities rarely correlate regionally to each other (Fig. 5). It is possible that periods of more developed fruticulture correspond with the establishment of big cities and/or agglomerated settlements in lowland plains. Upland land-use and abandonment is believed to be due to both climate change and human socio-economic changes (O'Rourke, 2006; Davies, 2007). Searching for a climatic cause of land-use dynamics in the Almalou area necessitates the access to high resolution palaeoecological records from the study area which are not available yet. The cross-correlation of oxygen isotope curves with pollen data from both lakes Zaribar (Zeribar) and Mirabad in the Zagros Mountains suggest two possible dry periods centred around 1500 and $500 \mathrm{cal} \mathrm{BP}$ (Stevens et al., 2006). None of these drought events can be correlated to the cultural phases distinguished in the Almalou record. Such a correlation cannot also be established for the global rapid climate change events recorded for the late Holocene (Mayewski et al., 2004). As several other studies have concluded (e.g. Heim et al., 1997; Yasuda et al., 2000; Neumann et al., 2007), it seems that in the Near East, historical events played a more important role than climate change in influencing cultural changes. One exception, however, is the Little Ice Age, whose extent and duration was enough to affect the local socio-economy during the 16 th to mid 19th centuries, as is evident in the Almalou record and several other palaeoecological records of the Near East (Kroonenberg et al., 2007; Ramezani et al., 2008).

\section{Conclusions}

The particular physiography and hydrology of Lake Almalou makes it a good site for the study of upland agricultural activities in the highlands of northwestern Iran. Variations in the anthropogenic herb and cultivated tree pollen as well as changes in frequencies of some aquatic pollen and non-pollen palynomorphs were used to detect phases of agriculture/pasture, fruticulture and to infer the environmental and climatic changes. Furthermore, lithology and variations of the pollen of aquatic plants were used to describe the late Holocene hydrological evolution of the Almalou crater bog. The slightly varied pollen percentages of regional vegetation notably Quercus, Artemisia, and Chenopodiaceae appeared less informative for understanding the regional environmental and climatic changes.

The Almalou bog was an open-water lake with a littoral belt of macrophytic vegetation and Cyperaceae/moss peat at least until approximately 3400 cal BP. Centripetal peat formation which had already started before 3400 cal BP continued and probably accelerated since then to almost completely cover the crater leaving only a small deep central pond at present.

The first significant human intervention is the appearance of tree cultivation in Iron Age and later Mannaean and Urartian periods. Agro-pastoral activities were extensively practiced during the Achaemenid period. However, during the Parthian Empire, the NW Iran and E Anatolia had unstable socio-economic conditions because of numerous conflicts between Romans and Persians over the Armenian territory. This fact may explain the absence of fruticultural and agricultural activities corresponding to the Parthian period. A few centuries later, during the realm of Sassanid Empire, an important fruticultural phase took place lasting for about two centuries. This may indicate a stability in political and socioeconomic situation of the region applied by this powerful Persian Empire. This fruticultural phase was apparently provisionally interrupted after the Islamic conquest and became soon re-established but never reached its pre-Islamic extent. The effect of the Mongol invasion (1219 AD) and the socio-economic instability of late Timurid period (ca. $1440 \mathrm{AD}$ ) may correspond to the near total absence of tree cultivation and the decline of the upland agricultural practices. Human activities in the form of agro-pastoral activities and fruticulture are not so obvious in the Almalou pollen diagram during the Safavid Dynasty. This may partly be explained by climatic deterioration of the Little Ice Age which is expressed in the Almalou record as higher lake water levels resulted from lower summer temperatures and/or higher annual precipitations. It may also be related to the episodic socio-economic instability caused by the border conflicts between the Safavids and Ottoman Turks which led to several occupations and then recoveries of the Iranian Azarbaijan including Tabriz. During the dark ages of the history of Iran (13th-16th centuries) and the Safavid era, the dominant lifestyle could have been the nomadism which is still practiced in the high massifs of the NW Iran. The introduction and cultivation of $R$. communis was however, practiced in the area during the Safavid reign. Agro-pastoral activities were largely intensified during the 17 th and 18th centuries and fruticulture notably as walnut (Juglans) cultivation has become extensively practiced during the last century. 


\section{Acknowledgement}

This work has been partly supported by the Iranian Center for International Research and collaboration (CISSC) and French embassy in Tehran within the framework of the Franco-Iranian Gundishapour project.

\section{References}

Adams, R.M., 1981. Heartland of Cities. Surveys of Ancient Settlement and Land Use on the Central Floodplain of the Euphrates. Chicago.

Andrieu-Ponel, V., Ponel, P., de Beaulieu, J.-L., Bruneton, H., Leveau, P., Goeury, C. Huttunen, R.L., Jull, A.J.T., 2000. Dix mille ans d'histoire de la végétation de BassProvence révélés par l'analyse pollinique de deux nouveaux profils sédimentaires du marais des Baux. Travaux du Centre Camille Jullian 26, 39-61.

Behre, K.E., 1981. The interpretation of anthropogenic indicators in pollen diagrams. Pollen et Spores 23, 225-245.

Behre, K.E., 1990. Some reflections on anthropogenic indicators and the record of prehistoric occupation phases in pollen diagrams from the Near East. In: Bottema, S., Entjes-Nieborg, G., van Zeist, W. (Eds.), Man's Role in the Shaping of the Eastern Mediterranean Landscape. Balkema, Rotterdam, pp. 219-229.

Berberian, M., Arshadi, S., 1977. On the evidence of the youngest activity of the North Tabriz Fault and the seismicity of Tabriz city. In: Berberian, M. (Ed), Contribution to the Seismotectonics of Iran, Part II. Geological Survey of Iran, vol. 39, pp. 397-418.

Berberian, M., King, G.C.P., 1981. Towards a paleogeography and tectonic evolution of Iran. Canadian Journal of Earth Sciences 18, 210-265.

Beug, H.J., 2004. Leitfaden der Pollenbestimmung für Mitteleuropa und angrenzende Gebiete. Verlag Dr Friedrich Pfeil, München.

Birken, A., 1976. Die Provinzen des osmanischen Reiches. Wiesbaden.

Birks, H.J.B., Birks, H.H., 1980. Quaternary Palaeoecology. Edward Arnold, London.

Blench, R., 2003. African crops in prehistoric South Asia: a critical review. In: Neumann, K., Butler, A., Kahlheber, S. (Eds.), Food, Fuel and Field: Progress in African Archaeobotany. Heinrich-Barth-Institut, Köln, pp. 273-292.

Bordet, P., Berberian, M., Alavi-Tehrani, N., Lotfi, M., 1976. Sur la géologie du massif du Sahand (Azerbaidjian-Iran occidental). Comptes Rendus de l'Académie des Sciences, Paris, t. 283, Serie D 13, 1481-1484.

Bosworth, C.E., 1989. Azerbaijan. In: Yarshater, E. (Ed.), Encyclopaedia Iranica. Islamic History to 1941, vol. 3. Bibliotheca Persica Press.

Bottema, S., 1986. A late Quaternary pollen diagram from Lake Urmia (northwestern Iran). Review of Palaeobotany and Palynology 47, 241-261.

Bottema, S., Woldring, H., 1984. Late Quaternary vegetation and climate of southwestern Turkey, Part II. Palaeohistoria 26, 123-149.

Bottema, S., 1992. Prehistoric cereal gathering and farming in the Near East: the pollen evidence. Review of Palaeobotany and Palynology 73, 21-33.

Bottema, S., 1995. Holocene vegetation of the Van area: Palynological and chronological evidence from Sögütlü, Turkey. Vegetation History and Archaeobotany 4, 187-193.

Bottema, S., Woldring, H., 1990. Anthropogenic indicators in the pollen diagrams of the Eastern Mediterranean. In: Bottema, S., Entjes-Nieborg, G., van Zeist, W. (Eds.), Man's Role in the Shaping of the Eastern Mediterranean Landscape. Balkema, Rotterdam, pp. 231-264.

Boyle, J.A. (Ed.), 1968. The Cambridge History of Iran; V. 5: the Saljuq and Mongol Periods. Cambridge University Press, Cambridge.

Bradley, R.S., Briffa, K.R., Cole, J.E., Hughes, M.K., Osborn, T.J., 2003. The climate of the last millennium. In: Alverson, K., Bradley, R.S., Pedersen, T.F. (Eds.), Paleoclimate, Global Change and the Future. Springer Verlag, Berlin, pp. 105-141.

Burney, C.A., 1961. Excavations at Yanik Tepe, North-West Iran. Iraq 23, 138-153.

Burney, C.A., 1962. Excavations at Yanik Tepe, Azerbaijan, 1961: second Preliminary Report. Iraq 24, 134-149.

Burney, C.A., 1964. The excavation at Yanik Tepe, Azerbaijan, 1962: third Preliminary Report. Iraq 26, 54-61.

Burney, C.A., Lang, D.M., 1972. The People of the Hills, Ancient Ararat and Caucasus. Weidenfild \& Nicoldon, London.

Coon, C.S., 1951. Cave Explorations in Iran, 1949. In: Museum Monographs. The University Museum, University of Pennsylvania, Philadelphia.

Coope, G.R., 1986. Chironomid analysis. In: Berglund, B.E. (Ed.), Handbook of Holocene Palaeoecology and Palaeohydrology. John Wiley \& Sons, Chichester, pp. 703-713.

Dandamaev, M., Lukonin, V.G., 1989. The Culture and Social Institutions of Ancient Iran, Cambridge.

Danti, M., 2006-2008. Hasanlu Publication Project. http://www.hasanlu.org/ (accessed 06.09.08).

Davies, A.L., 2007. Upland agriculture and environmental risk: a new model of upland land-use based on high spatial-resolution palynological data from West Affric, NW Scotland. Journal of Archaeological Science 34, 2053-2063.

De Candolle, A., 1964. Origin of Cultivated Plants. Hafner, New York.

Dyson Jr., R.H., Young Jr., T.C., 1960. The Solduz valley, Iran: Pisdeli Tepe. Antiquity $34,19-28$

Edwards, M., 1986. "Urmia Ware" and its distribution in north-western Iran in the Second Millennium B.C.: a review of the results of excavations and surveys. Iran 24, 57-77.
Ehrich, R.W., 1992. Chronologies in Old World Archaeology, third ed., vol. I. The University of Chicago Press, Chicago.

Gershevitch, I. (Ed.), 1985. The Cambridge History of Iran; V. 2: the Median and Achaemenian Periods. Cambridge University Press, p. 964.

Grimm, E.C., 1987. Coniss: a Fortran 77 program for stratigraphically constrained cluster analysis by the method of incremental sum of squares. Computers and Geosciences 13, 13-35.

Grimm, E.C., 2004/2005. TILIA and TGView Software. Ver 2.0.2. Illinois State University, Illinois.

Guiot, J., Nicault, A., Rathgeber, C., Edouard, J.-L., Guibal, F., Pichard, G., Till, C., 2005 Last-millennium summer-temperature variations in western Europe based on proxy data. The Holocene 15, 489-500.

Gyselen, R., 1989a. La géographie administrative de l'empire sassanide. Les témoignages sigillo-graphique, Paris.

Gyselen, R., 1989b. Note de me,trologie sassanide. Les drahms de Khusro II. Revue Belge de Numismatique et de Sigillographie 135, 5-23.

Heim, C., Nowaczyk, N.R., Negendank, J.F.W., Leroy, S.A.G., Ben-Avraham, Z., 1997 Near East desertification: evidence from the Dead Sea. Naturwissenschaften 84 398-401.

Hofmann, W., 1984. Stratigraphie subfossiler Cladocera (Crustacea) und Chironomidae (Diptera) in zwei Sedimentprofilen des Meerfelder Maares. Courier Forschungsinstitut Senckenberg 65, 67-80.

Hofmann, W. 1986. Chironomid analysis. In: Berglund, B.E. (Ed.), Handbook of Holocene Palaeoecology and Palaeohydrology. John Wiley \& Sons, Chichester, pp. 715-727.

Hopf, M., Willerding, U., 1988. Pflanzenreste. In: Bastam II, (Ed.), Ausgrabungen in den urartäischen Anlagen 1977-1978. W. Kleiss, Gebr. Mann Verlag, Berlin, pp. 263-318. + pls

Huff, D., 1969-74. Takht-I Suleiman. Iran 7-12.

Huff, D., 1978. Survey of excavations in Iran-1977. Takht-I Suleiman. Iran 16, 194-195.

Huff, D., 1977. Survey of Excavations in Iran-1976: Takht-I Suleiman. Iran 15, 179-181

Ilyashuk, E.A., Ilyashuk, B.P., Hammarlund, D., Larocque, I., 2005. Holocene climatic and environmental changes inferred from midge records (Diptera: Chironomidae, Chaoboridae, Ceratopogonidae) at Lake Berkut, southern Kola Peninsula Russia. The Holocene 15, 897-914.

Innocenti, F, Manetti, P. Mazzuoli, R, Pasquaré, G, Villari, L, 1982. Anatolia and north-western Iran. In: Thorpe, R.S. (Ed.), Andesites. John Wiley \& Sons, Chichester, pp. 327-349.

Jackson, P., Lockhart, L. (Eds.), 1986. The Cambridge History of Iran; V. 6: the Timurid and Safavid Periods. Cambridge University Press, Cambridge.

Klein, C., 1994. La vegetation altitudinale de l'Alborz Central (Iran). Institut Français de recherche en Iran, Tehran.

Kleiss, W., 1973a. Survey of Excavations in Iran 1971-72: Bastam. Iran 11, 185-188.

Kleiss, W., 1973b. Reports on Bastam, Leilan, Kale Zohak, etc. Archaologische Mitteilungen aus Iran, 6, Berlin, 163ff.

Kleiss, W., 1974. Survey of Excavations in Iran 1972-73: Bastam. Iran 12, 205-207.

Kleiss, W., 1977. Survey of Excavations in Iran 1971-62: Vermessungen und survery urartaischer platze in Azerbaidjan 1976. Iran 15, 181-182.

Kleiss, W., Kroll, S., 1979. Vermessene urartäische Plätze in Iran (West-Azerbaidjan) und Neufunde (Stand der Forschung 1978). Archaologische Mitteilungen aus Iran $12,183 \mathrm{ff}$.

König, F.W., 1934. Die älteste Geschichte der Meder und Perser. In: Heinrichs, J.C. (Ed.), Der Alte Orient, vol. 33. Leipzig Verlag, Leipzig, pp. 3-4.

Kroonenberg, S.B., Abdurakhmanov, G.M., Badyukova, E.N., van der Borg, K. Kalashnikov, A., Kasimov, N.S., Rychagov, G.I., Svitoch, A.A., Vonhof, H.B., Wesselingh, F.P., 2007. Solar-forced $2600 \mathrm{BP}$ and Little Ice Age highstands of the Caspian Sea. Quaternary International 173-174, 137-143.

Luterbacher, J., Xoplaki, E., 2003. 500-Year winter temperature and precipitation variability over the Mediterranean area and its connection to the large-scale atmospheric circulation. In: Bolle, H.-J. (Ed.), Mediterranean Climate, Variability and Trends. Springer, Berlin, pp. 133-153.

Mauquoy, D., Engelkes, T., Groot, M.H.M., Markesteijn, F., Oudejans, M.G., van der Plicht, J., van Geel, B., 2002. High-resolution records of late-Holocene climate change and carbon accumulation in two north-west European ombrotrophic peat bogs. Palaeogeography, Palaeoclimatology. Palaeoecology 186, 275-310.

Mayewski, P.A., Rohling, E.E., Stager, J.C., Karlén, W., Maasch, K.A., Meeker, L.D. Meyerson, E.A., Gasse, F., van Kreveld, S., Holmgren, K., Lee-Thorp, J., Rosqvist, G., Rack, F., Staubwasser, M., Schneider, R.R., Steig, E.J., 2004. Holocene climate variability. Quaternary Research 62, 243-255.

McGovern, P.E., Glusker, D.L., Exner, L.J., Voigt, M.M., 1996. Neolithic resinated wine. Nature 381, 480-481.

Medvdskaya, I., 1988. Who destroyed Hasanlu IV? Iran 26, 1-15.

Melikishvili, G., 1949. Voprosi istorii Maneyskogo tsarstva. Vest. Drevney istorii 1 57-72.

Miller, N.F., 2003. Archaeobotany in Iran, past and future. In: Miller, N.F., Abdi, K. (Eds.), Yeki bud, yeki nabud, Essays on the archaeology of Iran in honoor of William M. Sumner. Cotsen Institute of Archaeology Monograph 48, Los Angeles, pp. 8-15.

Miller, N.F., Sweeter than wine. Antiquity, in press.

Minorsky, V., 1957. Mongol place-names in Mukri Kurdistan. Mongolica, 4. In: Bulletin of the School of Oriental and African Studies, vol. 19. University of London. 58-81.

Moore, P.D., Webb, J.A., Collinson, M.E., 1991. Pollen Analysis, second ed. Blackwell Scientific Publications, Oxford. 
Moller Pillot, H.K.M., Buskens, R.F.M., 1990. De larven des Nederlanse Chironomidae (Diptera). Deel C: autoekologie en verspreiding. Nederlanse faunistische Medelingen $1 \mathrm{C}$.

Mostaufi, H.-A., 1340. The Geographic Part of the Nuzhat-al-Qulub. (G. Le Strange E.F.W. Gibb, Trans) Memorial Series, vol. 23. Luzac \& Co., London, 1919.

Naumann, R., Naumann, E., 1976. Takht-i Suleiman. Katalog der Ausstellung München, 26.

Nesje, A., Dahl, S.O., 2003. The 'Little Ice Age' - only temperature? The Holocene 13 139-145.

Neumann, F., Schölzel, C., Litt, T., Hense, A., Stein, M., 2007. Holocene vegetation and climate history of the northern Golan heights (Near East). Vegetation History and Archaeobotany 16, 329-346.

O'Rourke, E., 2006. Changes in agriculture and the environment in an upland region of the Massif Central, France. Environmental Science Policy 9, 370-375.

Potito, A.P., Porinchu, D.F., Donald, G.M., Moser, K.A., 2006. A late Quaternary chironomid-inferred temperature record from the Sierra Nevada, California, with connections to northeast Pacific sea surface temperatures. Quaternary Research 66, 356-363.

Quinlan, R., Smol, J.P., 2001. Setting minimum head capsule abundance and taxa deletion criteria in chironomid-based inference models. Journal of Paleolimnology 26, 327-342

Rahimi-Laridjani, F., 1988. Die Entwicklung der Bewässerungslandwirtschaft im Iran bis in Sasanidisch-frühislamische Zeit. In: Beiträge zur Iranistik, vol. 13 Wiesbaden.

Ramezani, E., Joosten, H., Marvie Mohadjer, R., Knapp, H.-D., Ahmadi, H., 2008. The late-Holocene vegetation history of the Central Caspian (Hyrcanian) forests of northern Iran. The Holocene 18, 305-319.

Reille, M., 1992. Pollen et spores d'Europe et d'Afrique du Nord. Laboratoire de botanique historique et de palynologie, Marseille.

Reille, M., 1995. Pollen et spores d'Europe et d'Afrique du Nord. Laboratoire de botanique historique et de palynologie-Supplément 1, Marseille.

Reille, M., 1998. Pollen et spores d'Europe et d'Afrique du Nord. Laboratoire de botanique historique et de palynologie-Supplément 2, Marseille.

Rivas-Martinez, S., Sánchez-Mata, D., Costa, M., 1997. Syntaxonomical synopsis of the potential natural plant communities of North America I. Itinera Geobotanica 10, 5-148.

Roberts, N., Wright Jr., H.E., 1993. Vegetational, lake-level and climatic history of the Near East and Southwest Asia. In: Wright Jr., H.E., Kutzbach, J.E., Webb III, T. Ruddiman, W.F., Street-Perrot, F.A., Bartlein, P.J. (Eds.), Global Climates since the Last Glacial Maximum. University of Minnesota Press, Mineapolis, pp. 194-220.

Sadek-Kooros, H., 1976. Survey report. Earliest Hominid Traces in Azerbaijan. Iran $14,154$.

Serre-Bachet, F., 1994. Middle Ages temperature reconstructions in Europe, a focus on northeastern Italy. Climatic Change 26, 213-224.

Stevens, L.R., Wright, H.E., Ito, E., 2001. Proposed changes in seasonality of climate during the Lateglacial and Holocene at Lake Zeribar, Iran. The Holocene 11 747-755.

Stevens, L.R., Ito, E., Schwab, A., Wright Jr., H.E., 2006. Timing of atmospheric precipitation in the Zagros Mountains inferred from a multi-proxy record from Lake Mirabad, Iran. Quaternary Research 66, 494-500.

Stockmarr, J., 1971. Tablets with spores used in absolute pollen analysis. Pollen et Spores 13, 615-621.

Stuiver, M., Reimer, P.J., Bard, E., Beck, J.W., Burr, G.S., Hughen, K.A., Kromer, B. McCormac, G., van der Plicht, J., Spurk, M., 1998. INTCAL98 Radiocarbon age calibration 24,000-0 cal BP. Radiocarbon 40, 1041-1084.
Sumner, W.M., 1986. Achaemenid settlement in the Persepolis Plain. American Journal of Archaeology 90, 3-31.

Touchan, R., Xoplaki, E., Funkhouser, G., Luterbacher, J., Hughes, M.K., Erkan, N., Akkemik, U., Stephan, J., 2005. Reconstructions of spring/summer precipitation for the Eastern Mediterranean from tree-ring widths and its connection to large-scale atmospheric circulation. Climate Dynamics 25, 75-98.

Turner, S.D., Brown, A.G., 2002. Vitis pollen dispersal in and from organic vineyards: I. Pollen trap and soil pollen data. Review of Palaeobotany and Palynology 129, 117-132.

Vallenduuk, H.J., Moller Pillot, H.K.M., 2002. Key to the larvae of Chironomus in Western Europe. Schijndel.

Van Geel, B., 1978. A palaeoecological study of Holocene peat bog sections in Germany and the Netherlands, based on the analysis of pollen, spores and micro- and macroscopic remains of fungi, algae, cormophytes and animals. Review of Palaeobotany and Palynology 25, 1-120.

Van Geel, B., Aptroot, A., 2006. Fossil ascomycetes in Quaternary deposits. Nova Hedwigia 89, 313-329.

Van Geel, B., Coope, G.R., van der Hammen, T., 1989. Palaeoecology and stratigraphy of the Lateglacial type section at Usselo (The Netherlands). Review of Palaeobotany and Palynology 60, 25-129.

Van Zeist, W., 1967. Late Quaternary vegetation history of western Iran. Review of Palaeobotany and Palynology 2, 301-311.

Van Zeist, W., Bottema, S., 1977. Palynological investigations in western Iran. Palaeohistoria 19, 19-85.

Van Zeist, W., Bottema, S., 1991. Late Quaternary vegetation of the Near East. Beihefte zum Tübinger Atlas, Reihe A, 18. Reichert, Tübingen.

Van Zeist, W., Woldring, H., Stapert, D., 1975. Late Quaternary vegetation and climate of southwestern Turkey. Palaeohistoria 17, 53-143.

Voigt, M.M., 1983. Haji Firuz Tepe, Iran: the Neolithic Settlement. University Museum, Philadelphia.

Wenke, R.J., 1975-6. Imperial investments and agricultural developments in Parthian and Sassanian Khuzestan. 1509 B.C. to A.D. 640. Mesopotamia 10-11, 31-221.

Wick, L., Lemcke, G., Sturm, M., 2003. Evidence of Lateglacial and Holocene climatic change and human impact in eastern Anatolia: high-resolution pollen, charcoal, isotopic and geochemical records from the laminated sediments of Lake Van, Turkey. The Holocene 13, 665-675.

Wiederholm, T., 1983. Chironomidae of the Holarctic region. Keys and diagnoses. Part I: Larvae. Entomologica Scandinavica Supplement No. 19.

Woldring, H., Bottema, S., 2001/2002. The vegetation history of east-central Anatolia in relation to archaeology: the Eski Acigöl pollen evidence compared with the Near Eastern environment. Palaeohistoria 43-44, 1-34.

Yarshater, E. (Ed.), 1983a. The Cambridge History of Iran; V. 3(1): the Seleucid, Parthians and Sassanid Periods. Part 1 of 2. Cambridge University Press Cambridge.

Yarshater, E. (Ed.), 1983b. The Cambridge History of Iran; V. 3(2): the Seleucid, Parthians and Sassanid Periods. Part 2 of 2. Cambridge University Press, Cambridge.

Yasuda, Y., Kitagawa, H., Nakagawa, T., 2000. The earliest record of major anthropogenic deforestation in the Ghab Valley, northwest Syria: a palynological study. Quaternary International 73/74, 127-136.

Zohary, M., 1983. Man and vegetation in the Middle East. In: Holzner, W. Werger, M.J.A., Ikusima, I. (Eds.), Man's Impact on Vegetation. Dr W. Junk Publishers, The Hague, pp. 287-295.

Zohary, D., Hopf, M., 1994. Domestication of Plants in the Old World, second ed. Clarendon Press, Oxford 